\title{
ヒツジを用いた動物介在イベントが参加者の 唾液アミラーゼ活性に及ぼす影響
}

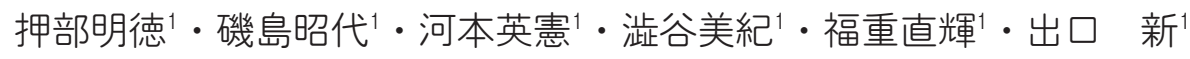 \\ 1 農業・食品産業技術総合研究機構・東北農業研究センター, 盛岡市 020-0198
}

(2011. 6. 21 受付, 2011. 9. 8 受理)

\begin{abstract}
要 約家畜を用いた動物介在イベントが，参加者に生理的影響を及ぼすか否かを明らかにするため に，ヒツジを用いた動物介在イベントを開催し，父母と子で構成される家族単位で参加した 36 家族, 123 人のイベント参加前後の唾液アミラーゼ活性を測定した。 その結果, 参加者全体のイベント参加後 の唾液アミラ一ゼ活性を参加前のそれと比較した場合，有意な差は認められなかった。しかし，基本属 性と動物飼育の経験に基づいてグループ分けすると，男子ではイベント参加後に唾液アミラーゼ活性の 減少が認められ，また，動物を飼っている女性においても減少が認められた。一方，現在は動物を飼っ ていないが過去に飼った経験のある母ではイベント参加後に唾液アミラーゼ活性の増加が認められた. これらの結果から家畜を用いた動物介在イベントが参加者に及ぼす生理的影響には性差および年齢差が 存在し，さらに動物飼育に関わる経験による影響を受けることが示唆された。
\end{abstract}

日本畜産学会報 82 (4), 391-395, 2011

動物とのふれあいは，ヒトに，血圧を安定させるなど

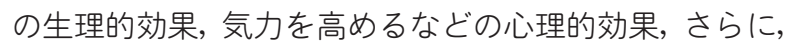
他人とのふれあいを拡げるなどの社会的効果を及ぼす事 が実証されている（Friedmannら 1980 ; Baun ら 1984 ; Eddy ら 1988 ; Morrison 2007). これらの効果は animalassisted interventions として, 疾病治療の目的で実施さ れる動物介在療法, および疾病治療を目的とせず, 情緒 的な安定や教育, あるいはレクリエーションを目的とし て実施される動物介在活動に応用されている (Morrison 2007). 本邦でも, 飼い犬などの愛着を感じるコンパニオ ン・アニマルに触れることによって, 飼い主がリラック ス状態や癒し効果が得られることや，イヌによる動物介 在活動が認知症の高齢者の日常生活の質の向上に貢献す ることなどが既に報告されている（金児 2006 ; 太湯ら 2008). また, コンパニオン・アニマルではない家畜を用 いた動物介在活動は, 多くの観光牧場などにおいてヒ ツジなどを用いて行われている. さらに, 䋶纈と関口 （2003）は農学系学部也獣医・産業動物系の大学教育に おける人と動物の絆の再認識, および，一般消費者に畜 産を身近なものと感じせしめる上での動物介在教育の重 要性を述べている. しかし, 家畜を用いた動物介在活動 が参加者の心理あるいは生理に及ぼす効果の客観的な評 価については極めて限られた情報しかない(永井ら 2004 ; 䋶䋶ら 2006). 家畜を用いた動物介在活動の客観的な評
価は, 観光牧場などで行われている動物介在活動や消費 者の牧場見学などの効果の裏付けとなり, 農業動物の食 用以外の新たな用途の開拓，さらに，それによる消費者 の畜産業への共感の増加にもつながる可能性がある.

本研究は，ヒツジを用いる動物介在活動が，父母と子 で構成される家族単位で参加した参加者に生理的影響を 及ぼすか否かを，ヒトの交感神経の克進度合いを非侵襲 性で簡易に推定する方法として用いられつつある唾液ア ミラーゼ活性の変化を指標として評価することを目的に 実施した。

\section{材料および方法}

農業・食品産業技術総合研究機構・東北農業研究セン ターにおいて, 約 50 平方メートルの柵内に放牧された 約 8 頭のチェビオット種とコリデール種の交雑種ヒツジ に，乾草を任意の時間柵越しに給与する『ヒツジとのふ れあいイベント』を実施した（図 1).イベントへの参加 者（以下，パネル）は父母と子で構成される家族に限定 した。パネルは先ず，唾液アミラーゼ活性測定者（以下， 測定者）から実験の概略と唾液採取方法の説明を受け, その後, 唾液アミラーゼモニター用チップ（二プロ株式 会社，大阪）を正確に 30 秒間，舌下に㨂入し，チップ中 の濾紙へ吸着させた．測定者は唾液を吸着したチップを 直ちに唾液アミラーゼモニター（ニプロ株式会社）に挿

連絡者：押部明徳（fax：019-643-3556, e-mail : comet@affrc.go.jp） 
入し唾液アミラーゼ活性を測定し, 得られた值をイベン 卜参加前 (以下, 参加前) の唾液アミラーゼ活性とした。 パネルはその後, 任意の時間, 柵越しにヒツジに飼料を 給与するなどした後，再度，同様に喠液を採取した。測 定者は参加前と同一の唾液アミラ一ゼモニターを用いて 唾液アミラ一ゼ活性を再度測定し, 得られた值をイベン 卜参加後 (以下, 参加後) の唾液アミラーゼ活性とした。 その後, パネルの基本属性と動物飼育に関する情報を, パネルに表 1 に示す質問を，面談および質問用紙により 質問し，それに対する回答を得た。イベント参加前後の 値の差の有無はWilcoxon の符号付順位和検定により判 定した. また, イベント参加前の值のグループ間, 即ち, 男女間, 父と母間, 男子と女子間, 親と子間, 父と男子 間および母と女子間の差の有無は Wilcoxon の順位和検 定により判定した.

\section{結果}

パネルの総数は 123 人 (36 家族) であり, 父母, 各 36 名 (平均年齢 $41 \pm 10$ 歳), 男子 22 名 (平均年齢 $9 \pm 7$ 歳) および女子 26 名（平均年齢 $10 \pm 8$ 歳）であった。これ らに加えて性別記録の欠損した子 3 名が存在した。ま た，動物飼育に関する質問に対する回答が欠損したパネ ルが 5 名存在した。 パネル全体および基本属性と動物飼 育の経験によりグループ分けしたパネルの唾液アミラー ゼ活性および統計的有意差を表 2 に示す。イベント参加

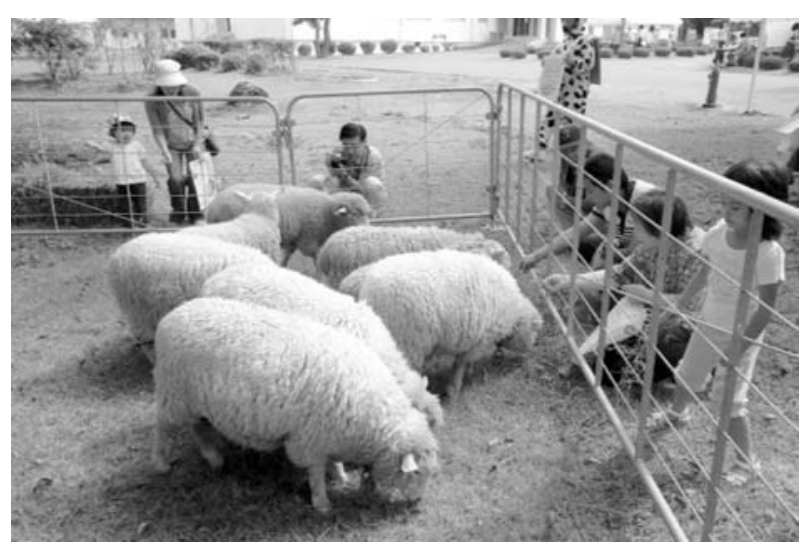

Figure 1 Scenery of the animal-associated event involving sheep.
前の唾液アミラーゼ活性は $2 \mathrm{kIU} / \mathrm{L}$ から $225 \mathrm{kIU} / \mathrm{L}$ の範 井であり参加後は $3 \mathrm{kIU} / \mathrm{L}$ から $197 \mathrm{kIU} / \mathrm{L}$ の範囲であっ た。イベント参加前の唾液アミラーゼ活性の值を, 男性 と女性間, 父と母間, 男子と女子間, 親と子間, 父と男 子間および母と女子間について統計的な差を判定した結 果, 男性の値が女性の值よりも高かった。参加者全体の イベント参加後の唾液アミラーゼ活性の値を参加前のそ れと比較した場合, 有意な差は認められなかった。しか し，質問への回答別にグループ分けし，イベント参加前 後の差を判定した結果, 子全体, さらに, 男子において, また，動物を飼っている人，さらに，動物を飼っている 女性においてイベント参加後の唾液アミラーゼ活性の值 が参加前のそれに比較して低くなった。逆に, 現在は動 物を飼っていないが過去に飼った経験のある母ではイベ ント参加後の唾液アミラーゼ活性の值は参加前のそれに 比較して高くなった。

\section{考察}

動物との触れあいが自律神経系に及ぼす効果を Koike ら（2004）は心拍の変動よる心臟の副交感神経活性の評 価を行った結果, イヌによる動物介在療法は, 心臓の副 交感神経活動を活性化することを報告している，本実験 で用いた唾液アミラーゼモニターは唾液線から分泌され る唾液中の $\alpha-$ アミラーゼ活性を測定することにより交 感神経の克進度合いを推定する方法であり，この方法に よって測定されるアミラーゼ活性と主観的なストレス変 化との間には関連があり，この簡易ストレス評価の妥当 性はある程度保証できると報告されている（辻と川上 2007 ; 山口 2007 ; 山口ら 2007 ; Yamaguchi と Sakakima 2007)。唾液を用いたストレス評価に関して，唾液中のス トレスマーカーは個人差が大きい事が報告されている (井澤ら 2007 ; 山口ら 2007). 本実験においてもパネル の唾液アミラーゼ活性に大きな個人差が認められた。本 実験において男性のイベント参加前の唾液アミラ一ゼ活 性が女性のそれよりも高かった。この現象は，男女の唾 液アミラーゼ活性を測定し, 男性の方が女性よりも有意 に高い値を示すとする村上ら（2009）の報告と一致する.

コンパニオン・アニマルではない家畜を用いた動物介 在活動の効果について, 永井ら（2004）はブ夕と肉牛が 飼育される農場で, 滞在型の動物介在教育を体験した農

Table 1 Questions to individuals in the panel

Question 1. Gender : Male/Female

Question 2. How old are you?

Question 3. At present, do you feed any animal (s) in your home?

If your answer is "yes," then specify the animal.

Question 4. Have you fed any animal (s) in the past?

(This question is addressed to persons who answered "no" to Question 3). 
Table 2 Deference between saliva amylase activity before and after participation in the event

\begin{tabular}{|c|c|c|c|}
\hline \multirow[b]{2}{*}{ Group (number of persons) } & \multirow{2}{*}{$\begin{array}{l}\text { Deference } \\
\text { between saliva } \\
\text { amylase activity } \\
\text { before and after } \\
\text { participation in } \\
\text { the event* }\end{array}$} & \multicolumn{2}{|c|}{$\begin{array}{l}\text { Saliva amylase activity (KIU/L) } \\
\text { mean } \pm \text { standerd deviation }\end{array}$} \\
\hline & & $\begin{array}{l}\text { Before } \\
\text { participation } \\
\text { in the event }\end{array}$ & $\begin{array}{c}\text { After } \\
\text { participation } \\
\text { in the event }\end{array}$ \\
\hline Whole panel (123) & NS & $43.8 \pm 37.1$ & $44.0 \pm 38.9$ \\
\hline Fathers and sons (58) $†$ & NS & $52.3 \pm 41.2^{A * *}$ & $47.7 \pm 41.1$ \\
\hline Mothers and daughters (62) $†$ & NS & $36.6 \pm 31.8^{\mathrm{B} * *}$ & $40.5 \pm 37.6$ \\
\hline Fathers (36) & NS & $56.4 \pm 45.3$ & $56.6 \pm 46.9$ \\
\hline Mothers (36) & NS & $39.0 \pm 32.8$ & $50.8 \pm 40.6$ \\
\hline Sons and daughters (51) & $P<0.05$ & $38.3 \pm 31.9$ & $30.2 \pm 25.9$ \\
\hline Son $(22) \dagger$ & $P<0.05$ & $45.6 \pm 33.5$ & $33.3 \pm 24.1$ \\
\hline Daughter $(26) \dagger$ & NS & $33.2 \pm 30.7$ & $26.3 \pm 27.9$ \\
\hline Persons who currently feed animals (44) & $P<0.05$ & $48.1 \pm 46.8$ & $39.1 \pm 38.6$ \\
\hline Persons who currently do not feed animals (79) & NS & $41.4 \pm 30.6$ & $46.6 \pm 39.1$ \\
\hline Fathers and sons who currently feed animals (18) & NS & $61.2 \pm 56.7$ & $51.1 \pm 44.9$ \\
\hline Mothers and daughters who currently feed animals (26) † & $P<0.05$ & $39.0 \pm 36.9$ & $30.9 \pm 32.0$ \\
\hline $\begin{array}{l}\text { Person who had fed animals in the past but do not } \\
\text { currently feed animals }(37)+\end{array}$ & $P<0.05$ & $37.8 \pm 30.4$ & $52.2 \pm 47.3$ \\
\hline $\begin{array}{l}\text { Person who had not fed animals in the past and do not } \\
\text { currently feed animals }(37)+\end{array}$ & NS & $46.6 \pm 31.6$ & $43.7 \pm 31.2$ \\
\hline $\begin{array}{l}\text { Fathers who had fed animals in the past but do not } \\
\text { currently feed animals (12) }\end{array}$ & NS & $49.8 \pm 41.3$ & $62.2 \pm 55.9$ \\
\hline $\begin{array}{l}\text { Mothers who had fed animals in the past but do not } \\
\text { currently feed animals (12) }\end{array}$ & $P<0.01$ & $37.1 \pm 23.4$ & $62.7 \pm 44.5$ \\
\hline $\begin{array}{l}\text { Sons and daughters who had fed animals in the past but } \\
\text { do not currently feed animals (8) }\end{array}$ & NS & $21.6 \pm 16.6$ & $14.8 \pm 4.6$ \\
\hline
\end{tabular}

* Difference was tested using Wilcoxon matched-pairs signed-ranks test

** Significant difference between different superscript letters. Difference was tested using Wilcoxon ranks test : NS, not significant

†Excluding 3 children whose genders were not recorded

+Excluding 5 persons with no records of feeding animals in the past

学部の大学生の体験前, 体験中および体験後の気分尺度 の変化と血圧など生理指標を測定した結果, 体験前に比 較して，体験中以降に「抑うつ」などの否定的な気分を 表す尺度の減少を見いだしている. また，續縜ら（2006） も教育ファームでの活動が都市生活を営む学生の心理な どに及ぼす影響を調べた結果, ブタを用いた活動中に積 極的な気分と生き生き感が上昇し, 否定的な気分亡重圧 感が減少することを報告している，本実験では，パネル 全体のイベント参加前後の唾液アミラーゼ活性に有意な 差は認められなかったが, 基本属性と動物飼育の経験に 基づいてグループに分けた場合，参加前に比べて参加後 の値が減少する, すなわち, 参加前に比べて交感神経活 動が抑制されたと推定されるグループが存在し, 初対面 の家畜を用いた動物介在活動によっても, 生理的な変化 が生じることが示唆された。年齢に関して, Neupertら （2007）は約 1000 人について人間関係，ネットワークお
よび仕事によるストレスに対する感情的および肉体的反 応を調査した結果，年齢増加により，ストレスに対する 感情的および肉体的反応が低くなる事を報告している. 動物に対する意識の性差について, Eldridge と Gluck （1996）は大学生の動物実験に対する意識調査を行った 結果，女性は男性より動物保護運動を支持し，一方，男 性は女性よりも動物実験から得られる潜在的な利点を強 調するなどの性差があることを報告している，本実験の 調査項目は，年齢や性が動物介在イベントの効果発現に 影響を及ぼすメカニズムの解明には不十分である。しか し, 本実験によって, 親全体ではイベント参加前後の值 に差は認められないが, 子全体では参加後の値が減少 し，また，女子では差は認められないが，男子で参加後 の值が減少した。これらの結果から，年齢および性が動 物介在イベントの効果発現に影響を及ぼす事が示唆され た. 動物飼育の経験との関わりで，本実験では動物を 
飼っている人，さらに，動物を飼っている女性において イベント参加後の値に減少が認められた. 動物を飼って いる人は，飼っていない人に比べて動物に対して受容的 で肯定的であることが想像され，そのため動物介在イベ ントを快適な刺激として感じ, 交感神経活動が抑制され た，リラックスした状態になり易いと推察された。一方, 現在は動物を飼っていないが過去に飼った経験のある母 ではイベント参加後に値の増加が認められた。現在は動 物を飼っていないが過去に飼った経験があると回答した パネルは，死別あるいは生別に拘わらず飼育した動物と の離別を経験している. 山田（2010）はペットとの死別 の反応に関わる要因分析を行い, 悲嘆反応には性差が存 在し, 女性の方が男性より高いと報告している. 飼育し た動物と離別の経験があり，かつ，現在は動物を飼って いない女性，すなわち，本実験での母のグループでは， 動物介在活動によって, 過去に経験した悲しみなどの負 の記憶が呼び起こされ, 交感神経え進状態になる可能性 も考えられた。本実験の調査項目は，現在は動物を飼つ ていないが過去に飼った経験のある母のイベント参加後 の値の増加原因の特定には充分ではない.しかし，この 結果は動物介在イベントの効果が過去の動物飼育経験か らも影響を受ける事を示唆している。

\section{謝辞}

本研究結果は『ヒツジとのふれあいイベント』に参加 した盛岡市立北厨川小学校の生徒とその父母, 一般参加 家族および東北農業研究センターの関係職員のご協力に より得られたものであり，ここに感謝の意を表する.

\section{文献}

Baun MM, Bergstrom N, Langston NF, Thom L. 1984. Physical effects of human companion animal bonding. Nurasing Researach 33, 126-129.

Eddy J, Hart LA, Boltz RP. 1988. The effect of service dogs on social acknowledgements of people in wheelchairs. The Journal of Psychology 122, 39-45.

Eldridge JJ, Gluck JP. 1996. Gender differences in attitudes toward animal research. Ethics and Behavior 6, 239-256.

Friedmann E, Katcher AH, Lynch JJ, Thomas SA. 1980. Animal companions and one-year survival of patients after discharge from a coronary care unit. 1980. Public Health Report 95, 307-312.

井澤修平, 城月健太郎, 菅谷 渚, 小川奈美子, 鈴木克彦, 野村 忍。2007。唾液を用いたストレス評価一採取及び測定手順 と各唾液中物質の特徵. 日本補完代替医療学会誌 4, 91101.

金児 恵. 2006. コンパニオン・アニマルが飼い主の主観的幸 福感と社会的ネットワークに与える影響. 心理学研究 77, $1-9$.

Koike H, Matsui H, Kaneko M, Kamata T, Motooka M, Suzuki T, Yokoyama T. 2004. The effect of animal assisted therapy with a dog on the autonomic nervous system. The K/TAKANTO Medical Journal 54, 1-4.

䋶纐雄三, 松井明日香, 門間 俊, 関口知典. 2006. 養豚教育 ファームでの活動が都市生活を営む農学部学生の心理・生 理と養豚への理解に及ぼす影響. 日本養豚学会誌 43, 1-10.

䋶䋶雄三, 関口知典. 2003. 農業動物の福祉そして動物介在教 育の研究における疫学の役割. 獣医疫学雑誌 7, 101-106.

Morrison ML. 2007. Health benefits of animal assisted interventions. Complementary Health Practice Review 12, 51-62.

村上 満, 田原祐助, 竹田一則, 山口昌樹. 2009. 唾液アミラー ゼ活性は中学生の心身ストレスの指標になり得るか. 生体 医工学 47, 166-171.

永井久美子, 佐藤 謖, 䋶纐雄三. 2004. 滞在型の動物介在教育 が都市生活を営む農学部学生の農業動物への認識と気分・ 生理に及ぼす影響. 明治大学農学部研究報告 140,9-23.

Neupert SD, Almeida DM, Charles ST. 2007. Age differences in reactivity to daily stressors: The role of personal control. Journals of Gerontology Series B 62, 216-225.

太湯好子, 小林春男, 永瀬仁美, 生長豊健. 2008. 認知症高齢者 に対するイヌによる動物介在療法の有用性. 川崎医療福祉 学会誌 17, 353-361.

辻 弘美, 川上正浩. 2007. アミラーゼ活性に基づく簡易ス卜 レス測定器を用いたストレス測定と主観的ストレス反応測 定との関連性の検討. The human science research bulletin of Osaka Shoin Women's University 6, 63-73.

山田弘司. 2010. ペットの死別時の反応と経過に関わる要因分 析一学生の調査一. ヒトと動物の関係学会誌 $25,52$.

山口昌樹. 2007. 唾液マーカーでストレスを測る。日本薬理学 杂隹誌 129, 80-84.

山口昌樹, 花輪尚子, 吉田 博. 2007. 唾液アミラーゼ式交感神 経モ二夕の基礎的性能. 生体医工学 45, 161-168.

Yamaguchi M. Sakakima J. 2007. Evaluation of driver stress in a motor-vehicle driving simulator using a biochemical marker. Journal of International Medical Research 35, 91-100. 


\title{
Influence of animal-assisted feeding using sheep on salivary amylase activity of individuals participating in the event
}

\author{
Akinori OSHIBE', Akiyo ISOJIMA', Hidenori KAWAMOTO', Miki SHIBUYA', \\ Naoki FUKUJYU' and Shin DEGUCHI \\ ${ }^{1}$ Tohoku Agricultural Research Center, National Agriculture and Food Research Organization, \\ Morioka, Iwate 020-0198, Japan \\ Corresponding : Akinori OSHIBE (fax : +81 (0) 19-643-3556, e-mail : comet@affrc.go.jp)
}

Salivary amylase activity (SAA) of 123 individuals from 36 families who participated in an animal-assisted feeding using sheep as models were measured in order to evaluate the effect of other domestic animalassisted feeding on the physical status of the participants. For all the participants, SAA measured after participation did not significantly differ from that measured before participation. However, in the case of sons and daughters who are currently feeding animals, the SAA measured after participation was lesser than that measured before participation. In the case of mothers who had fed animals in the past but currently do not feed animals, the SAA measured after participation was greater than that measured before participation. The results indicate that age and gender affected the physical status of the individuals who participated in the animal-assisted event using sheep. The results also indicate that an experience in animal feeding influences the physical status of the participants.

Nihon Chikusan Gakkaiho 82 (4), 391-395, 2011

Key words : animal-assisted-activity, salivary-amylase, sheep. 